\title{
La família biològica en l'àmbit de la protecció a la infància: processos d'acció socioeducativa
}

\author{
Entitat que finança: Ministeri de Ciència e Innovació \\ I+D EDU2011-30144-C02-01/02.
}

(2012-2014)

\section{Resum de la recerca}

El grup GRISIJ (Grup de Recerca sobre Intervencions socioeducatives en la Infància i la Joventut), format perinvestigadors de la Universitat de Barcelona, de la Universitat de Lleida i de la Universitat Rovira i Virgili, està duent a terme el projecte de recerca $\mathbf{L} \boldsymbol{a}$ família biològica en l'àmbit de la protecció a la infància: processos d'acció socioeducativa.

La finalitat d'aquesta investigació és contribuir al coneixement dels processos necessaris per a la reunificació de les famílies que estan en el sistema de protecció de la infància. Concretament pretenem elaborar un Programa de Suport per a les famílies biològiques que tenen els seus fills i filles en una mesura de separació provisional (acolliment familiar o residencial), per promoure el desenvolupament de les seves capacitats parentals i fomentar els processos de resiliència de tots els membres de la família.

La contribució científica que proporciona el present projecte està relacionada amb el coneixement científic i innovador respecte a la realitat de la intervenció amb famílies i amb la protecció de la infància, i encaixa amb dos reptes en protecció a la infància en el context del Programa Marc I + D de la Unió Europea "Family Life": incorporar en els processos formatius a la família biològica i oferir suport a aquestes per aconseguir la reunifació familiar.

Centrant el focus d'estudi en la família biològica, el projecte donarà com a producte un programa de formació per a la família biològica i els fills i filles en situació d'acolliment. Aquest ha de donar resposta a les necessitats de tots dos per garantir la possibilitat de reunifació. Per a això, se centrarà la intervenció socioeducativa en 
quatre moments del procés: durant la separació del nen o la nena, el seguiment de l'acolliment, la reunifació familiar i la post-reunifació familiar. Els resultats pretenen contribuir a la millora en la qualitat de vida de la infància i les seves famílies. En aquest sentit obre un possible ventall d'estudis que, fins ara, no s'han investigat, ja que el caràcter innovador dels objectius plantejats, creix en orientar aquesta investigació a la recerca de la seva repercussió per a l'acció socioeducativa en els casos de protecció de la infància que ha requerit la separació del nucli familiar.

Els objectius de la recerca són:

1. Identificar les necessitats específiques de les famílies i dels fills i filles en situació de separació com a mesura de protecció, des de l'òptica dels protagonistes i dels tècnics de protecció a la infància.

2. Analitzar la realitat personal, familiar i social de les famílies amb fills i filles que estan en diferents mesures de protecció a la infància que impliquen la separació del nucli familiar.

3. Elaborar un Programa de Suport per a las famílies biològiques que tenen els seus fills i filles sota una mesura de separació provisional (acolliment familiar o residencial), per a promoure el desenvolupament de les seves capacitats parentals i fomentar els processos de resiliència de tots els membres de la família.

El projecte es desenvolupa en diferents fases:

A. Fase de coneixement-comprensió de l'estat de la qüestió. Creació del Marc teòric.

B. Fase d'entrada en escenari i recollida de dades. Aquesta fase ha estat possible gràcies a la col-laboració i participació de les famílies, adolescents i professionals del sistema de protecció a la infància de quatre comunitats autònomes (Catalunya, Illes Balears, Cantabria i Galícia). Respecte als professionals s'han dut a terme 9 grups de discussió, on han participat un total de 63 persones; respectes a les famílies, s'han realitzat 8 grups de discussió, on han participat 42 persones (34 d'aquestes estaven reunificades), i respecte als nens i nenes s'han realitzat 16 entrevistes individuals i 5 grupals en les que han participat un total de 30 nens i nenes i adolescents.

C. Fase de comprensió i anàlisi de les necessitats formatives de les famílies biològiques que tenen els seus fills en acolliment familiar o acolliment residencial. Transformació de les necessitats dels grups de discussió en els objectius i continguts per l'elaboració d'un programa de formació i suport per a les famílies biològiques que tenen els seus fills en acolliment familiar o residencial. De l'anàlisi dels grups de discussió, el grup GRISIJ elaboraria una primera proposta de programa adreçat a les famílies biològiques. 
D. Fase final. Aplicació pilot del programa, un cop finalitzat l'elaboració provisional del programa, cadascuna de les comunitats autònomes, aplicarà una part del mateix per avaluar la seva adequació inicial i posteriorment es farà l'elaboració definitiva del Programa de suport a les famílies biològiques.

Partint d'aquesta visió resilient de la capacitació i preservació familiar, es proposa un projecte innovador en quant a la seva metodologia (treball grupal amb la família biològica i els fills i filles en situació d'acolliment), projecte que encaixa dins de les prioritats del Pla estratègic nacional d'infància i Adolescència (2006-2009) i dins de les polítiques socials nacionals i internacionals.

Quant a la seva utilitat i contribució tècnica, atès que el present projecte ha estat plantejat com una resposta a les necessitats sentides i manifestades pels professionals i responsables dels Serveis de Protecció a la Infància i Adolescència, es pot dir que és una investigació beneficiosa per a la totalitat dels professionals que treballen amb les famílies i amb els nens i nenes en situació de protecció de la infància. El benestar del nen i la nena passa per la capacitat de la seva família (pares) en exercir de manera competent les seves funcions. Capacitar les famílies per prevenir la situació de risc o desemparament del menor (preservació familiar) és molt important, però també ho és, treballar amb aquelles que en un moment determinat no van saber afrontar les seves funcions i obligacions parentals. Aquestes, necessiten que es generi coneixement sobre els processos d'intervenció socioeducativa amb les famílies biològiques. El projecte permetrà avenços científics per donar resposta a les necessitats educatives d'aquestes famílies, actuant amb elles i no sobre elles.

\section{Investigadores Principals}

M. Àngels Balsells Bailón. Universitat de Lleida.

Crescencia Pastor Vicente. Universitat de Barcelona.

\section{Membre del grup GRISIJ}

Carmen Ponce Alifonso. Universitat Rovira i Virgili 